\title{
Empirical Study on the Impact of Commercial Bank Income Structure on Profitability
}

\section{Zengfeng Ji}

The School of Economics, Shanghai University, Shanghai, China

Email address:

jizengfeng@126.com

\section{To cite this article:}

Zengfeng Ji. Empirical Study on the Impact of Commercial Bank Income Structure on Profitability. International Journal of Economics, Finance and Management Sciences. Vol. 3, No. 5, 2015, pp. 599-603. doi: 10.11648/j.ijefm.20150305.32

\begin{abstract}
With the development of banking business and the deepening of market competition, the rate of interest income in the bank's overall revenue became smaller and smaller. More banks began to divert attention to the pioneering types of services, and increasing non-interest income. According to the general theory of academia, the currently 14 listed China's commercial banks can be divided into large joint-stock banks, medium-sized joint-stock banks and city commercial banks. Based on annual data from 2008-2014 of each listed commercial banks, we did quantitative analysis of the impact of income structure on commercial bank profitability. Analysis showed that the proportion of non-interest income (fees and commission income accounted for in the total income of) in all income and net interest margin made a positive impact on the bank profitability. In addition, macroeconomic performance also had a positive impact on bank profitability. For the national joint-stock banks and city commercial banks, loans had a negative impact on profitability.
\end{abstract}

Keywords: China's Commercial Bank, Income Structure, Profitability, Empirical Study

\section{Introduction}

In the 21 st century, the proportion of the financial sector in the country economy is becoming bigger, and getting a more important position. The development level of the financial sector has become an important indicator of overall national strength. The global financial crisis in 2007, which began in the United States, generated economic losses and caused the destructive power and made people acutely aware of the significance to foster a financial system with moderate risk and efficience. In particular, to build a banking system that can both tolerate risk, encourage financial derivatives and service innovation, and ensure market order security and stable, so as to avoid systemic risk in the banking system, has very important significance for global economic development and national stability. Since the reform and opening up, China's financial industry is developing rapidly, but the capital market activity still has a gap when compared with developed countries. Banking industry in the overall financial indutry is particularly important, therefore the stability of commercial banks is directly related to the country's financial development, and even has a huge impact on the real economy as well as on the overall national economic situation. From this perspective, we believe that analyzing the current development of China's commercial banks, exploring the income structure and the influence of the income structure on their level of profitability, has great significance.

Wang Juan, Wang Manshu etal. and Lu Jing etal. selected a sample of China's commercial banks, analyzes the impact of bank income structure of bank profitability. [3] [4] [9]

Dai Xiaolong and Wang Wei said that with the process of China's interest rate market speeding up, commercial banks should pay attention to their capital adequacy ratio, change the extensive mode of development. [1] [10]

Alatengsudao, Wang Xiaolong etal.and Zhao Lin etal. think that non-interest income has significant influence on bank's income structure in China, macroeconomic factors also have a positive impact on earnings income of the banks. [5] [6] [7]

\section{Variable Selection and Data Illustrated}

\subsection{Variable Selection}

The choice of samples in this article is based on research needs and data quality. At present China's listed commercial banks with a total of 16 , due to the agricultural bank of China and China everbright bank have a delay time to market, from the perspective of a published annual report data is not complete and the quality is not high due to data of individual 
years missing, therefore not included the two banks in this article research scope. In this paper, the research sample selection for the rest of the 14 listed China's commercial banks, namely, the bank of China, industrial and commercial bank of China, China construction bank, bank of communications, Ping'an bank, Minsheng bank, Shanghai pudong development bank, industrial bank, China merchants bank, Huaxia bank, China citic bank, bank of Beijing, Nanjing, Ningbo bank, etc. In this paper, data from Guotai Junan database, sample time selection from 2008 to 2014, a total of seven years. Panel data including 14 observations on cross section, 11 observations on time series, a total of 84 observations.

\subsection{The Selection of Model Indicators}

\subsubsection{Explained Variable Selection}

From the perspective of literature around the world, the measure of profitability indicators include return on equity, return on total assets, etc. In this paper, we select ROA (return on assets) as a measure of bank profitability indicators, because this variable measures the commercial banks to make use of the assets of the size of the income.

\subsubsection{Explanatory Variables Selection}

China's commercial bank's net operating income from two parts: net interest income and non-interest income, the net interest income belongs to the traditional banking business, rather than interest income is not the bank's traditional business, but in recent years, the latter's proportion of revenues gradually increase. Traditional lending and net interest income from securities investment business, have heterogeneity characteristics of non-interest income business, including service, trust, commission and trading revenue, etc.

NIM (Net Interest Margin) refers to a ratio between Net Interest income and bank's all interest-bearing assets, reflects the bank by controlling the for-profit assets and actively seeking low-cost source of funds, in order to realize the ability of the Interest income is greater than the Interest payments. Different NIM directly led to the bank's net interest income, so in this paper, the net interest margin as listed on the impact of commercial bank's net interest income on profitability.

The increase of non-interest income, not only can expand the initial profit space ofbanks, increase revenue, but also improve the banks' income structure diversification. Non-interest income mainly comes from the generalized off-balance sheet business, for this kind of income in most cases do not need to increase capital and assets scale, this means that the increase in non-interest income increase the efficiency of capital and assets. This paper use relative amounts (NIIR, the ratio between non-interest income and total revenues) as explanatory variables, mainly in order to ensure the metrics of comparability between different sizes of the bank.

Net interest margins, non-interest income ratio is this article focuses on variables, the two variables representing the banks' income structure. Through these indicators, the structure change can be observed when the bank income and the direction of diversification, the profitability of the banks is how to change.

\subsubsection{The Selection of Control Variable}

The main content of this article is to study the income structure of listed China's commercial banks affect profitability. In order to eliminate the influence of other factors on the explanatory variables, this article selects the two control variables related to the bank and a macroeconomic control variables to ensure the accuracy of the results.

Bank profitability is influenced by their own assets and business scale. Generally ,big banks are more likely to adopt new technology, have more extensive customer group lower operating costs, it is easier to achieve the economies of scope and economies of scale. Based on the total assets of the exponential LNASSET, and loan amount of logarithmic LNLOAN as bank relevant control variables in order to reduce the number of original sample for variable the exponential volatility, which increases the accuracy of the regression results.

Bank profits growth and the country's macro economy has close relationship. Only country economic grows steadily, banks can use good macro-economic environment to improve their profitability. A country's level of GDP on behalf of the state's overall macroeconomic situation, so this article selects the logarithm of GDP LNGDP as macro explanation variable of bank profitability.

\subsection{Methodology}

Due to the large-sized,medium-sized joint-stock banks and city commercial banks have their own different characteristics, if all listed banks in general analysis non-interest business impact on performance, this paper argues that it is quite wrong So this article listed banks can be divided into three groups, including the four large state-owned joint-stock banks (bank of communications, industrial and commercial bank, construction bank, bank of China), seven mid-sized national shareholding commercial banks (huaxia bank, citic bank, ping an bank, China merchants bank, Shanghai pudong development bank, minsheng bank, industrial bank), three city commercial banks (bank of Beijing, Nanjing, Ningbo), in order to establish a panel data to comparison research. This paper establish regression model is as follows:

$$
\begin{aligned}
& \mathrm{ROA}_{\mathrm{it}}= \alpha_{\mathrm{it}}+\beta_{1}(\mathrm{NIM})_{\mathrm{it}}+\beta_{2}(\mathrm{NIIR})_{\mathrm{it}}+\beta_{3}(\text { LNASSET })_{\mathrm{u}}+ \\
& \beta_{4}(\text { LNLONA })_{\mathrm{it}}+\beta_{5}(\text { LNGDP })_{\mathrm{it}}+\varepsilon_{\mathrm{it}}
\end{aligned}
$$

Because this article will analysis of three sets of data, so in this part, respectively, set up three panels, respectively is a large group of joint-stock banks PoolZGl, medium-sized group P001ZG2 joint-stock banks, city commercial bank group P001ZG3.

Table 1. Main Variable Average Time Change Tendency.

\begin{tabular}{llll}
\hline Year & ROA & NIM & NIIR \\
\hline 2008 & 1.012143 & 0.012581 & 0.102591 \\
2009 & 1.112143 & 0.014939 & 0.152906 \\
2010 & 1.033571 & 0.014435 & 0.162606 \\
2011 & 1.109286 & 0.018168 & 0.153338 \\
2012 & 1.212143 & 0.022549 & 0.170694 \\
2013 & 1.234286 & 0.026411 & 0.179331 \\
2014 & 1.200714 & 0.029098 & 0.201326 \\
\hline
\end{tabular}


Through the time series data, descriptive analysis of each variable. From table 1 can clearly see, from 2008 to 2014, total assets of commercial banks in China yield fluctuation is large, but net interest margin and non-interest income of basic show the stable situation of rising year by year.

Table 2. Main Variable Cross Section of Average in 2014

\begin{tabular}{llll}
\hline Year & ROA & NIM & NIIR \\
\hline $\begin{array}{l}\text { bank of China } \\
\begin{array}{l}\text { China construction bank } \\
\text { Industrial and commercial }\end{array}\end{array}$ & 1.13 & 0.046156 & 0.280444 \\
$\begin{array}{l}\text { bank of China bank of } \\
\text { communications }\end{array}$ & 1.295714 & 0.072616 & 0.197466 \\
$\begin{array}{l}\text { bank of communications } \\
\text { large state-owned }\end{array}$ & 1.118571 & 0.020051 & 0.172376 \\
$\begin{array}{l}\text { joint-stock banks } \\
\text { industrial bank }\end{array}$ & 1.222857 & 0.05019 & 0.212957 \\
$\begin{array}{l}\text { Shanghai pudong } \\
\text { development bank }\end{array}$ & 1.187143 & 0.010313 & 0.140384 \\
$\begin{array}{l}\text { Ping'an bank } \\
\text { Minsheng bank }\end{array}$ & 1.034286 & 0.011383 & 0.099283 \\
$\begin{array}{l}\text { China merchants bank } \\
\text { China citic bank }\end{array}$ & 0.824286 & 0.00482 & 0.148843 \\
$\begin{array}{l}\text { Huaxia bank } \\
\text { mid-sized national }\end{array}$ & 1.098571 & 0.011437 & 0.197733 \\
$\begin{array}{l}\text { shareholding banks } \\
\text { bank of Beijing }\end{array}$ & 1.315714 & 0.01419 & 0.201407 \\
$\begin{array}{l}\text { bank of Nanjing } \\
\text { bank of Ningbo } \\
\text { city commercial banks }\end{array}$ & 1.228571 & 0.002033 & 0.11408 \\
\hline
\end{tabular}

By cross-sectional descriptive analysis data of 2014 for each variable. As shown in table 2, from the point of the mean, the state-owned holding commercial large joint-stock bank's net interest margin and non-interest income accounts for more than two indicators were higher than medium joint-stock commercial banks and city firms. The bank of China is more prominent in non-interest income accounted for this metric is much higher than other large and medium-sized joint-stock banks, this is the result of the bank of China in the international settlement business advantage position, it is different from the core competencies of the trade. In Medium-sized joint-stock bank, Minsheng bank, China merchants bank of non-interest income is higher, and huaxia bank profitability is very poor, this is due to its high operating costs. In addition, the city commercial banks have a higher level of profitability, but the non-interest income is low, especially the bank of Beijing, thanks to its high yields low operating costs.

\section{The Construction of Regression Model}

\subsection{Unit Root Test}

Here the inspection way as the comprehensive inspection, including LLC, Breitung, ADF, etc. Including Hadri original hypothesis is that there is no unit root test, the test of the rest of the null hypothesis are unit root. In order to research facilities, this article only uses two methods of panel data unit root test, meaning that the same root unit root test LLC (Levin - Lin $\mathrm{Chu}$ ) inspection and different root unit root test Fisher - ADF test. If declined to exist in the two kinds of inspection unit root null hypothesis, we say this sequence is smooth, or the opposite is not smooth. Take NIIR results $\mathrm{P}$ values of various methods are less than 0.05 , therefore, reject the null hypothesis so can conclude that NIIR? There is no unit root is smooth.

First is the raw data of four panel unit root test. This article take the unit root test method for the same root unit testing LLC and different - ADF unit root test Fisher. Test results show that there are a few variables is not smooth, should be handled on the difference. However, due to the panel data of the year shorter in this paper, the difference significance is not big, so this paper still use the original data model.

\subsection{F test}

To estimate the fixed effects models and mixed models selection, will be the value $\mathrm{F}$ test. Relative to hybrid estimation model, is it necessary to establish individual fixed effects model can be done through $F$ test.

H0: For different cross section model intercept the same item (hybrid estimation model is set up)

H1: For different cross-sectional model of intercept (time fixed effects model)

F Statistics is defined:

$$
\mathrm{F}=[(\mathrm{SSEr}-\mathrm{SSEu}) /(\mathrm{T}-1)] /[\mathrm{SSEu} /(\mathrm{NT}-\mathrm{N}-\mathrm{k})]
$$

SSEr, SSEu respectively constraint model (mixed estimation model) and the constraint model (individual fixed effects model) of residual Sum of squares (the Sum of squared resid). The constraint model more than the constraint model $\mathrm{T}-1$ was estimated parameters. It should be pointed out that: when the model contains $\mathrm{k}$ explained variable, $\mathrm{F}$ statistic of the denominator degrees of freedom is NT-N- k. Through the $\mathrm{F}$ statistics, we will be able to choose accurate, the best estimate model.

Regression includes four steps:

The first step for mixed effects model: first in the cross section column select None Period is None; Weights are cross - section Weights and then copy the regression results of Sum squared resid, it is SSEr.

Step 2: individual Fixed effects model: choose in the cross section column Fixed Period is None; Weights are cross section Weights and then copy the regression results of Sum squared resid, it is SSEu

The third step: according to the formula $\mathrm{F}=[(\mathrm{SSEr}-$ $\mathrm{SSEu}) /(\mathrm{T}-1)] /[\mathrm{SSEu} /(\mathrm{NT}-\mathrm{N}-\mathrm{k})]$ to calculated the results. T for the number of whether our data is unbalance or balance, the observations line means the Total pool (balanced) observations: the value of but if this is the balance and we also can calculate the total number of companies each year. Every year, for example, we study 10 years are NT $=10$ and $500 \mathrm{x}$ $500=5000 . \mathrm{K}$ as an Explanatory variables do not contain Explained variable.

The fourth step: according to the result of calculation $\mathrm{F}$ 
value distribution table to see whether through inspection. Inspection standards: when $\mathrm{F}>\mathrm{F} \alpha(\mathrm{N}-1, \mathrm{NT}-\mathrm{N}-\mathrm{k}), \alpha=0.01,0.05$ or 0.1 , reject the conclusion of null hypothes, it should establish individual fixed effects model,or accept the null hypothesis that it can not set up individual fixed effects model .

qb $\mathrm{F}=18.5765014>\mathrm{F} 0.05(13,82) \approx 2$ to establish individual fixed effects model

qgxgf $\mathrm{F}=4.566546>\mathrm{F} 0.05(6,37) \approx 2$ to establish individual fixed effects model

gykg $\mathrm{F}=5.11373874<\mathrm{F} 0.05(3,19)=3.13 \quad$ to $\quad$ establish individual fixed effects model

cssy $\mathrm{F}=8.521987>\mathrm{F} 0.05(2,13)=3.80$ to establish individual fixed effects model

\subsection{H Test}

Fixed effect model is only applicable to the pump to the cross section of the unit the sample outside of the unit is not compatible. If the cross section data from a large overall extract, the individual as a random distribution is more suitable.To respect what should be established, individual random effects regression model or individual fixed effects regression model,by using Hausman statistics.

HO: Individual effect is not related to regression variables (individual random effects model)

H1: Individual effect is related to regression variables (individual fixed effects model)

\subsubsection{All the Sample Groups}

Table 3. Regression results of all samples.

\begin{tabular}{llll}
\hline Variable & Coefficient & t-value & Prob \\
\hline NIM & 0.278125 & 0.396889 & 0.0014 \\
NIIR & 0.185714 & 0.439956 & 0.0661 \\
LNASSET & -0.198466 & -1.196136 & 0.0234 \\
LNLOAN & 0.29788 & 1.75288 & 0.0832 \\
LNGDP & 0.231219 & 2.574481 & 0.0116 \\
R2 & 0.683729 & & \\
Adjusted R2 & 0.544801 & & \\
Prob(F-statisic) & 0.000000 & & \\
DW & 1.809443 & & \\
\hline
\end{tabular}

\subsubsection{Mid-Sized National Shareholding Commercial Banks}

Table 4. Regression results of mid-sized national shareholding commercial banks.

\begin{tabular}{llll}
\hline Variable & Coefficient & t-value & Prob \\
\hline NIM & 0.83114 & 0.49244 & 0.06253 \\
NIIR & 0.65375 & 0.86062 & 0.0395 \\
LNASSET & -0.424872 & -1.501033 & 0.01418 \\
LNLOAN & -0.70618 & -1.81899 & 0.077 \\
LNGDP & 0.990494 & 1.978413 & 0.0554 \\
R2 & 0.726868 & & \\
Adjusted R2 & 0.645667 & & \\
Prob(F-statisic) & 0.000000 & & \\
DW & 2.126390 & & \\
\hline
\end{tabular}

Because the quantity of individual random effect model requirements section more than variable coefficients to estimate the random effects, so 3. Gykg and 4. Cssy should choose individual fixed effects model.

\subsubsection{Large State-Owned Joint-Stock Banks}

Table 5. Regression results of large state-owned joint-stock banks.

\begin{tabular}{llll}
\hline Variable & Coefficient & t-value & Prob \\
\hline NIM & 0.903432 & 0.693477 & 0.04964 \\
NIIR & 0.617195 & 1.2629 & 0.02219 \\
LNASSET & -0.80521 & -1.58771 & 0.01289 \\
LNLOAN & 0.062119 & 0.196663 & 0.08462 \\
LNGDP & 1.017416 & 2.292496 & 0.03395 \\
R2 & 0.912708 & & \\
Adjusted R2 & 0.875953 & & \\
Prob(F-statisic) & 0.000000 & & \\
DW & 2.157818 & & \\
\hline
\end{tabular}

\subsubsection{The Listed City Commercial Bank}

Table 6. Regression results of the listed city commercial bank.

\begin{tabular}{llll}
\hline variable & coefficient & t-value & prob \\
\hline NIM & 0.7204 & 1.37157 & 0.0193 \\
NIIR & 1.337994 & 3.079868 & 0.0088 \\
LNASSET & -0.4421 & -1.37945 & 0.0191 \\
LNLOAN & -0.3111 & -1.06879 & 0.0346 \\
LNGDP & 1.498216 & 2.953479 & 0.0112 \\
R2 & 0.828643 & & \\
Adjusted R2 & 0.736374 & & \\
Prob(F-statisic) & 0.000410 & & \\
DW & 1.928834 & & \\
\hline
\end{tabular}

\subsubsection{Regression Results and Alysis}

Table 7. Annotation of this table.

\begin{tabular}{|c|c|c|c|c|c|c|c|c|}
\hline \multirow[t]{2}{*}{ Variable } & \multicolumn{2}{|c|}{ all samples } & \multicolumn{2}{|c|}{$\begin{array}{l}\text { National } \\
\text { joint-stock } \\
\text { Banks }\end{array}$} & \multicolumn{2}{|c|}{$\begin{array}{l}\text { Five major } \\
\text { state-owned } \\
\text { Banks }\end{array}$} & \multicolumn{2}{|c|}{$\begin{array}{l}\text { City } \\
\text { commercial } \\
\text { Banks }\end{array}$} \\
\hline & Cof & Prob & Cof & Prob & Cof & Prob & Cof & Prob \\
\hline NIM & 0.28 & 0.001 & 0.83 & 0.06 & 0.90 & 0.05 & 0.72 & 0.02 \\
\hline NIIR & 0.19 & 0.066 & 0.65 & 0.04 & 0.62 & 0.02 & 1.34 & 0.01 \\
\hline LNASSET & -0.20 & 0.023 & -0.42 & 0.01 & -0.81 & 0.01 & -0.44 & 0.02 \\
\hline LNLOAN & 0.30 & 0.083 & -0.71 & 0.08 & 0.06 & 0.08 & -0.31 & 0.03 \\
\hline LNGDP & 0.23 & 0.012 & 0.99 & 0.06 & 1.02 & 0.03 & 1.50 & 0.01 \\
\hline $\mathrm{R} 2$ & 0.68 & & 0.73 & & 0.91 & & 0.83 & \\
\hline $\begin{array}{l}\text { Adjusted } \\
\text { R2 }\end{array}$ & 0.54 & & 0.65 & & 0.88 & & 0.74 & \\
\hline $\begin{array}{l}\text { Prob } \\
\text { (F-statisic) }\end{array}$ & 0.00 & & 0.00 & & 0.00 & & 0.00 & \\
\hline DW & 1.81 & & 2.13 & & 2.16 & & 1.93 & \\
\hline
\end{tabular}

\section{Result and Discussion}

\subsection{The Overall Effect on Model}

Four model regression results show that the main explanation of the influence of variables to be interpreted the same direction and the significance, this paper set up the model of the whole is relatively stable. Each model of the four 
regression of R2 sample group were more than 0.5 , the fit of the model as a whole are high, considering the main explanation variables to explain the effect is remarkable.

\subsection{About the Explanatory Variables}

From the analysis results, the China's commercial bank's net interest margin (NIM), non-interest income ratio (NIIR) regression coefficients are significant, and the impact on the profitability of the banks is positive. In terms of regression results, specific to different types of commercial banks, in the three child only NIIR coefficient of city commercial banks in the sample group is greater than the coefficient of NIM, shows that the present stage China's city commercial bank's non-interest income contribution to the profitability more than the state-owned banks and national share-holding system is great, that is, in the state-owned banks and joint-stock banks national income structure, the traditional interest income still occupies a large proportion.

\subsection{About the Control Variable}

Regression results show that the return on assets ratio on bank's total assets is negative impact. This shows that in the business of bank, the expansion of the scale not only lead to improvements in performance, instead of falling bank return on total assets. Investigate its reason, lies in the blind expansion of bank assets, most likely in the consumption of huge cost at the same time, does not bring income increase. Banking marketization level rising in recent years, the increasingly fierce competition between commercial banks, some banks failed to timely change train of thought, through simple scale expansion is still trying to pursue the business performance of ascension, neglected the product innovation and improvement of service quality, this mode of operation does not improve performance. It is in this factor, under the drive of the listed banks are actively explore the road to transformation, efforts to strengthen business innovation, and create new performance growth, constantly optimize the income structure.

GDP for three kinds of the bank's return on total assets have more significant effect, shows that the level of GDP is an important control variables affect bank profitability. Upgrading the bank's total assets of yields and macroeconomic growth presents great consistency.

\subsection{Regression Results of Three Child Samples}

Through the analysis shows that the explanatory variables and control variables impact on bank rate of return on total assets and net worth, because of the different types of banks present different regression results.

State-controlled banks subsample regression results with all samples regression results are basically identical, except for the assets on bank profitability exist negative impact, the other four variables are positive.

National joint-stock commercial banks and city commercial banks ,these two child the sample regression results of the positive and negative effects. Results show that both net interest margins, non-interest income, GDP level has a significant positive effect on bank profits, in addition , assets scale and the credit scale exist negative effects on the profitability of banks.

This part makes a brief summary of the whole paper. Usually, there should be one paragraph in this part.

\section{Conclusion}

Analysis showed that the proportion of non-interest income (fees and commission income accounted for in the total income of) in all income and net interest margin made a positive impact on the bank profitability. In addition, macroeconomic performance also had a positive impact on bank profitability. For the national joint-stock banks and city commercial banks, loans had a negative impact on profitability.

\section{Acknowledgements}

I thank my tutor for his significant assistances and I also thank the students who help me to collect these data by questionnaires.

\section{References}

[1] Dai Xianglong. Commercial Bank Management[M]. Beijing: China's Financial Press, 1998: 69-95.

[2] Wang Zhijun. The European Banking Sector Non-interest Income. International Financial Research [J], 2004, (7): 47-52.

[3] Wang Juan. Non-interest Income and Its Impact on the Performance of Listed Banks of China's Study [D]. Southwestern University of Finance and Economics, 2013.

[4] Wang Manshu, Liu xiaofang. Commercial Banks to the Impact on the Profitability of Banks' Income Structure Research Based on the Analysis of the Data of 14 Listed Banks in China [J]. Nankai Management Review, 2013, 02: 143-149.

[5] Alatengsudao. The Influence Factors of China's Commercial Bank Profitability [D]. Chongqing University, 2013.

[6] Wang Xiaolong. China's Commercial Bank Income Structure Research [D]. Northeast University of Finance and Economics, 2012.

[7] Zhao Xin, Pan Yanyan, Zheng Hui. A Study of Profit Growth Capacity Effect of Commercial Banks' Income Structure Based on Non-Stationary Panel Model [J]. Journal of Ocean University of China, 2014, (5).

[8] Wan Jiaju. Income Structure Transformation of Commercial Banks in the Interest Market [J]. China Business Update, 2014, (13).

[9] Lu Jing,Alatengsudao, Yin Yuming. The Impact of Banks' Activity and Funding Strategies on Risk and Returns [J]. China Soft Science, 2013, (9).

[10] Wang Wei. Empirical Study on Cost Efficiency of China's Commercial Banks [J]. China Business and Market, 2014, 28(1). 